Vol 11, Issue 8, 2018

\title{
SYNTHESIS OF SOME NOVEL PERYLENE DI IMIDES AND EVALUATION OF THEIR ANTI CANCER ACTIVITY
}

\begin{abstract}
HEMALATHA CN ${ }^{1}$, VIJEY AANANDHI $\mathbf{M}^{2 *}$
${ }^{1}$ Research Scholar, Department of Pharmaceutical Chemistry, School of Pharmaceutical Sciences, Vels Institute of Science, Technology and Advanced Studies, VISTAS, Pallavaram, Chennai, Tamil Nadu, India. ${ }^{2}$ Department of Pharmaceutical Chemistry and Analysis, School of Pharmaceutical Sciences, Vels Institute of Science, Technology and Advanced Studies, Chennai, Tamil Nadu, India. Email: hodpchemistry@velsuniv.ac.in
\end{abstract}

Received: 10 April 2018, Revised and Accepted: 10 May 2018

\section{ABSTRACT}

Objective: The main objective of the study is to synthesis some novel perylene di imides and to evaluate for anti oxidant activity and anticancer activity.

Methods: Antioxidant assay was carried on to study the reducing activity of the compounds. The cytotoxicity assay was studied to find the best potent compound among the synthesized compound by using the HCT-116, a colon cancer cell line. Synthesized substituted amine derivatives of perylene di imides. From the evaluation study Compound, A shows potent activity when compared with the standard drug 5-Fluorouracil.

Results: The results of the total antioxidant capacity assay of perylene compounds are evaluated by the 1,1-diphenyl-2-picryl hydrazyl (DPPH) method and nitric oxide scavenging method. All the synthesized compounds are evaluated for their antioxidant power. From the results of DPPH and nitric oxide scavenging assay, Compound A, B, C and D showed potent activity when compared with the standard. For further evaluation of cell line studies, based upon the $\mathrm{IC}_{50}$ values, Compound $\mathrm{A}, \mathrm{B}$ and $\mathrm{C}$ were taken for study. The molecular modeling data's are exactly correlated with the in vitro studies. We have used 5-Fluorouracil and PIPER as a standard for in vitro study and molecular modeling study respectively.

Conclusions: From the results, Compound A will be efficient to inhibit telomerase enzyme and the Compound A will be effective for anti-cancer therapy.

Keywords: Perylene derivatives, QSAR plus, G-Quadruplex ligand database, Docking, Anti oxidant study, Cell line study.

(C) 2018 The Authors. Published by Innovare Academic Sciences Pvt Ltd. This is an open access article under the CC BY license (http://creativecommons. org/licenses/by/4. 0/) DOI: http://dx.doi.org/10.22159/ajpcr.2018.v11i8.26539

\section{INTRODUCTION}

G-Quartets are square planar arrangements of four guanine bases, which can form extraordinarily stable stacks when present in nucleic acid sequences [1,2]. Guanine-rich nucleic acids are well known for their ability to adopt non-Watson-Crick hydrogen-bonded structures $[3,4]$. These structures are well-known as G-Quadruplexes and share the common feature of stacked guanine tetrads as basic motif [5]. G-Quadruplexes are four-stranded guanine-rich DNA structure found at the ends of the eukaryotic telomeres. Human telomeric DNA is usually 4-14-kilo bases long and is comprised of TTAGGG tandem repeats. Upregulated telomerase activity in cancer cells maintains the length of telomeres after cell division, conferring immortality.

The role of G-Quadruplex and the telomerase activity has been studied since the early 1990s [6]. G-Quadruplex stabilization leads to inhibition of the telomerase activity, which induce the apoptosis. The compounds like perylene diimide (PDI), naphthalene diimide, oxazole, are the possible intercalators acting on the G-Quartet structure and stabilize it. For example, cationic porphyrin, quindoline and berberine, and trisubstituted are $\mathrm{O}$-alloxazines have been demonstrated to interfere with the oncogenic transcription in vitro. Quarfloxin, developed by cylene pharmaceuticals, entered clinical trials due to its ability to interact with G-Quadruplexes in vivo [7-10].

QSAR study has been carried out by V Life MDS Software-QSAR Plus Module to predict and compare the biological activity of standard and newly designed compounds. QSAR has been done by developing variable regression methods. The compounds are divided into training and test set compounds by manual selection, random and sphere exclusion methods. The models are developed and based on regression values; we selected eight equations to design new compounds of perylene di imides. Out of 497 compounds, 59 compounds possess better biological activity when compared with the standard compounds.

These 59 selected compounds from QSAR study has been chosen for docking study. Docking has been done by G-Quadruplex Ligand Database (G4LDB). This is an online database which was having in built tools and performed by open babel 2.3.0 to predict the binding affinity with the targets. The targets (1LIH, 1NZM, 3CE5, 3SC8 and 2HRI) for the docking are selected based upon

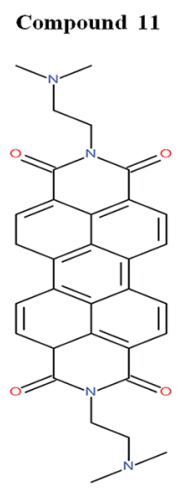

the literature survey and the selected compounds are docked. The results are visualized by Discovery studio Visualizer 4.1 Visualizer. From the results, 9 compounds are selected and the results of these compounds are visualized using Discovery Studio 4.1 Visualizer. To narrow down the results, 3 best compounds are selected and the 
compounds are Compound 11, Compound 20 and Compound 48. The hydrogen bond interactions and binding free energy levels, $p K i$ values are compared with the standard PIPER compound.

From the results of G4LDB Database, the 9 compounds are docked with the specific protein (PDB ID: 4B18), a telomerase protein. Docking has been done by Auto Dock 4.2. Finally, from the AutoDock results, Compound 11 shows good binding energy when compared with the standard PIPER compound. The study states as from the G4LDB Database 2 compounds posses good binding affinity, and from the Auto Dock Compound 11 possess good binding energy. As in our previous study from the in silico studies we studied structure activity relationship for the compounds and predicted biological activity, and by docking studies concluded the scaffold for the synthesis [11-13]. Molecular Docking Analysis was done by the output file of the docking that was generated after the study. The binding energy, Inhibition Constant, and the number of hydrogen bonds were considered for the analysis. Compound 11, 20 and 48 showed potent binding interactions with the protein 4B18 and compared with the standard PIPER.

The best compounds are compared with the standard PIPER and the binding energy values are showing more potent than the standard PIPER. The binding energy values for the compound 11, 20, 48 and PIPER are $-6.23,-6.42,-6.59$ and $-5.59 \mathrm{kcal} / \mathrm{mol}$ respectively. From the scaffold, we selected Compound 11 as a scaffold moiety and sketched a scheme for the synthesis of Perylene di imides targeting telomerase for anti-cancer activity.

\section{METHODS}

Starting materials are all commercially available reagents and solvents used as received except for statements. All solvents were purified using standard procedures. Reactions were monitored by thinlayer chromatography on pre-coated silica gel plates and visualized using ultraviolet irradiation $(254 \mathrm{~nm})$. Column chromatography was performed on silica gel (100-200 Mesh).

\section{Synthetic scheme}

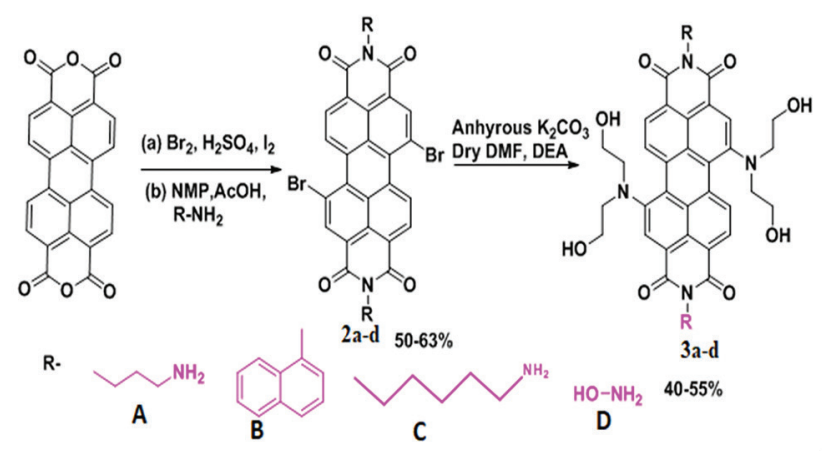

\section{Procedure}

Step 1: Bromination and condensation of PTCDA [14,15]

Preparation of dibromo-N,N-diamine substituted-3,4,9,10 perylene tetra carboxylic Diimides (2a,2b,2c and 2d)

To a solution of PTCDA compound $(1.0 \mathrm{~g}, 20 \mathrm{mmol})$ was added concentrated sulfuric acid $(200 \mathrm{~mL})$ which was then stirred for $24 \mathrm{~h}$ at room temperature. The mixture was warmed to $55-60^{\circ} \mathrm{C}$, and iodine $(0.12 \mathrm{~g}, 2.5 \mathrm{mmol})$ was added. After $5 \mathrm{~h}$, bromine $(3.3 \mathrm{~mL}, 62.5 \mathrm{mmol})$ was added to the mixture slowly which was then warmed to $80^{\circ} \mathrm{C}$ and stirred for $8 \mathrm{~h}$. The mixture was quenched with ice water and filtered under reduced pressure to give bromo compound. The crude Bromo Compound ( $500 \mathrm{mg}, 0.9 \mathrm{mmol})$, amines $\left(\mathrm{R}_{1}, \mathrm{R}_{2}, \mathrm{R}_{3}\right.$ and $\left.\mathrm{R}_{4}\right)$ and acetic acid (272 mg, $4.5 \mathrm{mmol}$ ) in $\mathrm{N}$-methyl-2-pyrrolidinone (NMP; $15 \mathrm{~mL}$ ) were stirred at $85^{\circ} \mathrm{C}$ under $\mathrm{N}_{2}$ for $12 \mathrm{~h}$. After cooling the mixture to room temperature and pouring into aqueous $\mathrm{HCl}(10$ vol.- $\%, 100 \mathrm{~mL})$, the precipitate was separated by suction filtration, washed with deionized water until $\mathrm{pH} 7$, washed and dried under vacuum. The crude product was purified by silica gel column Hexane-ethylacetate $4: 1, \mathrm{v} / \mathrm{v}, R \mathrm{f}=$ 0.71 - Compound $2 \mathrm{a}, R \mathrm{f}=0.61$ - Compound $2 \mathrm{~b}, R \mathrm{f}=0.42$ - Compound $2 \mathrm{c}$, $R \mathrm{f}=0.61$ - Compound $2 \mathrm{~d}$ ) as eluent and Compound $2 \mathrm{a}, 2 \mathrm{~b} 2 \mathrm{c}$ and $2 \mathrm{~d}$ was obtained after evaporation of the solvent as a red powder.

\section{Step 2: Alkylation of substituted and condensed dibromo PTCDA} Preparation of 1,7-Bis(n-diethanolamine)-N,N-disubstituted amines3,4,9,10-perylenetetracarboxylic diimides (3a,3b,3c and $3 \mathrm{~d})$

1,7-dibromo PDI (2a,b,c and d $0.1 \mathrm{mmol}$ ) was dissolved into $5 \mathrm{~mL}$ of dimethylformamide. To which diethylacetamide $(0.5 \mathrm{mmol})$ and potassium carbonate $\left(\mathrm{K}_{2} \mathrm{CO}_{3}, 0.5 \mathrm{mmol}\right)$ was added. The resulted mixture was then allowed reacted at $80^{\circ} \mathrm{C}$ for $15 \mathrm{~h}$. The reaction mixture was then powered into $15 \mathrm{~mL}$ water and the red solid was then re-dissolved in $20 \mathrm{~mL}$ dichloromethane (DCM) and washed with $1 \mathrm{~N}$ hydrochloric acid and then water each for 3 times. Then, DCM layer was dried over $\mathrm{Na}_{2} \mathrm{SO}_{4}$. After removal of DCM, the residue was applied to chromatography with $\mathrm{CH}_{2} \mathrm{Cl}_{2} /$ ethyl acetate (100:0-100:2) as eluents to afford the desired products $3 \mathrm{a}$, $3 \mathrm{~b}, 3 \mathrm{c}$ and $3 \mathrm{~d}$. The final synthesized compounds are tabulated in Table 1.

All the compounds are Characterize by IR, ${ }^{1} \mathrm{H}$ nuclear magnetic resonance (NMR), ${ }^{13} \mathrm{CNMR}$ and high resolution-mass spectrometry HRMS (electrospray ionization [ESI]). The results are as following.

Spectral results-Compound A Step 2:1,7-bis(n-diethanolamino)-N,Ndibutyl-3,4,9,10-perylenetetracarboxylic diimides-Compound A<smiles>CCCCN1C(=O)c2ccc3c4c(N(CCO)CCO)cc5c6c(ccc(c7c(N(CCO)CCO)cc(c2c37)C1=O)c64)C(=O)N(CCCC)C5=O</smiles>

$\mathbf{R}_{\mathrm{f}}=0.64(\mathrm{H}: \mathrm{EtOAc} / 1: 1)$

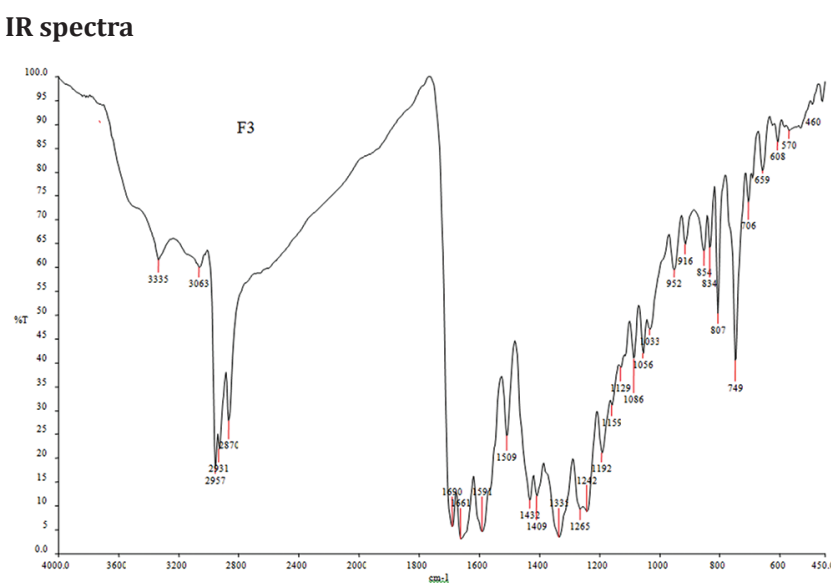

Result analysis

IR $\left(\mathrm{KBr}, \mathrm{cm}^{-1}\right)$ Hydroxyl group (3335 $\left.\mathrm{cm}^{-1}\right)$, Amide carbonyl (1710, $\left.1690 \mathrm{~cm}^{-1}\right)$, Aromatic CH $\left(3063,2957 \mathrm{~cm}^{-1}\right)$, Aliphatic CH $\left(2870 \mathrm{~cm}^{-1}\right)$, $\mathrm{C}=\mathrm{C}\left(1591 \mathrm{~cm}^{-1}\right)$; 
${ }^{1}$ HNMR spectra-3a (Compound A)

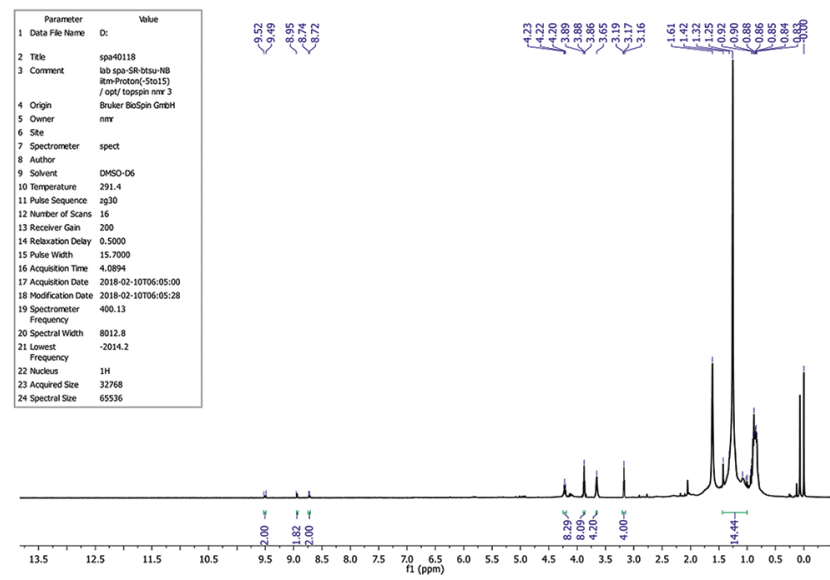

Result analysis

$\left.{ }^{1} \mathrm{H} \mathrm{NMR} \mathrm{(400} \mathrm{MHz,} \mathrm{CDCl}_{3}\right) \delta 9.52(\mathrm{~d}, \mathrm{~J}=15 \mathrm{~Hz}, 2 \mathrm{H}), 8.95(\mathrm{~s}, 2 \mathrm{H}), 8.74(\mathrm{~d}$, $\mathrm{J}=10 \mathrm{~Hz}, 2 \mathrm{H}), 4.23(\mathrm{t}, \mathrm{J}=10 \mathrm{~Hz}, 4 \mathrm{H}), 3.89(\mathrm{t}, \mathrm{J}=10 \mathrm{~Hz}, 4 \mathrm{H}), 3.65(\mathrm{~s}, 4 \mathrm{H}), 3.19$ (t, J=10Hz,4H), 1.61-0.83 (m, 12H) ppm;

${ }^{13}$ CNMR Spectra- 3a (Compound A)

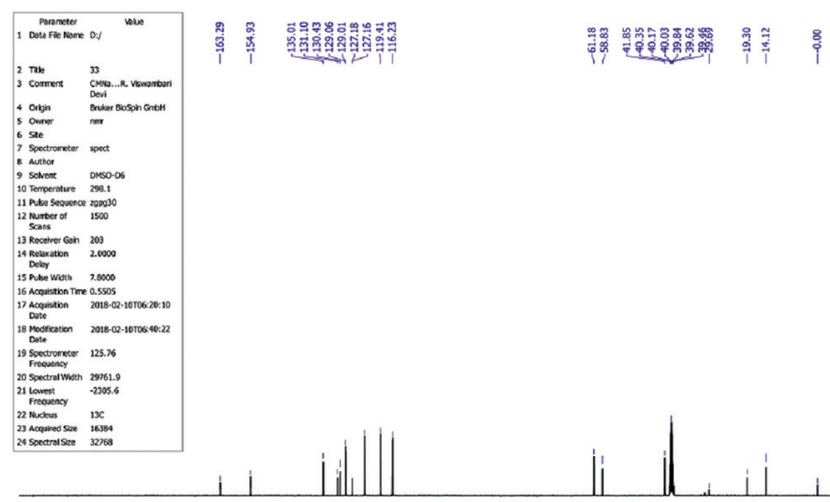

Result analysis

${ }^{13} \mathrm{C}$ NMR $\left(100 \mathrm{MHz}, \mathrm{CDCl}_{3}\right) \delta 163.29,154.93,135.01,131.01,130.43$, 129.06, 129.01, 127.18, 127.16, 119.41, 116.23, 61.18, 58.83, 41.85, 29.69, 19.30, $14.12 \mathrm{ppm}$;

\section{HRMS (ESI) spectra-3a (Compound A)}

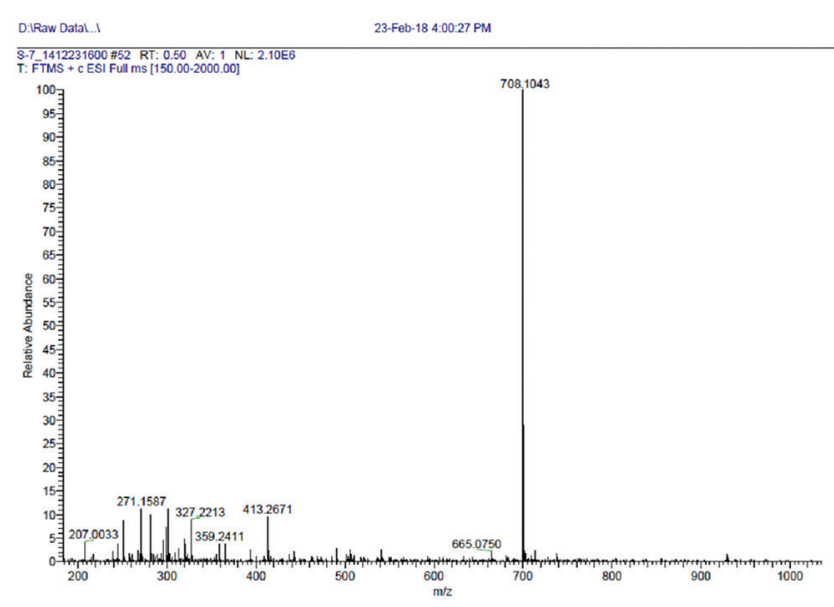

Result analysis

HRMS (ESI): Anal. Calcd. for $\left(\mathrm{C}_{40} \mathrm{H}_{44} \mathrm{~N}_{4} \mathrm{O}_{8}\right)(\mathrm{M}+)$ : 708.3159, Found: 708.1043 .

Spectral Results - Compound B Step 2: 1,7-Bis(n-diethanolamino)$\mathrm{N}, \mathrm{N}$-dinapthylamine-3,4,9,10-perylenetetracarboxylic diimides - Compound B.

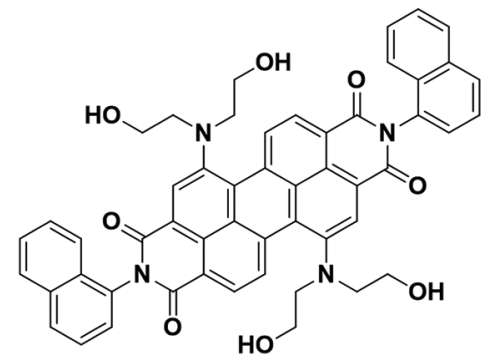

$\mathbf{R}_{\mathrm{f}}=0.70(\mathrm{H}: \mathrm{EtOAc} / 1: 1)$

IR Spectra - 3b

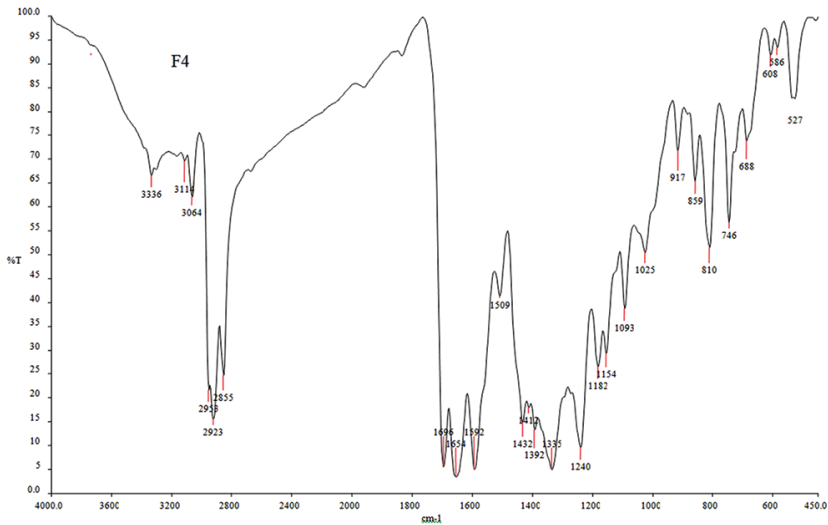

Result analysis

IR $\left(\mathrm{KBr}, \mathrm{cm}^{-1}\right)$; Hydroxyl group (3336 $\left.\mathrm{cm}^{-1}\right)$, Amide carbonyl (1712, $\left.1696 \mathrm{~cm}^{-1}\right)$, Aromatic $\mathrm{CH}\left(3114,3064,2953 \mathrm{~cm}^{-1}\right)$, Aliphatic $\mathrm{CH}$ $\left(2885 \mathrm{~cm}^{-1}\right), \mathrm{C}=\mathrm{C}\left(1592 \mathrm{~cm}^{-1}\right)$;

${ }^{1}$ HNMR Spectra - 3b (Compound B)

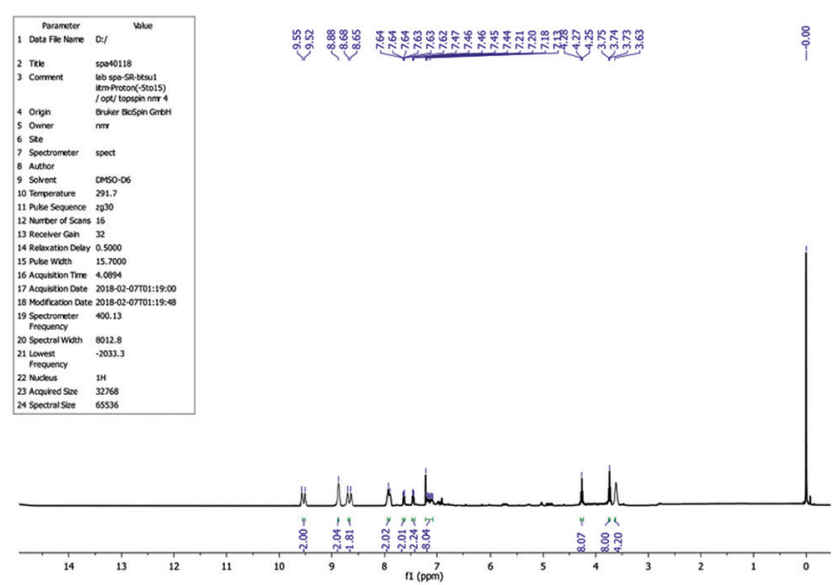

Result analysis

${ }^{1} \mathrm{H}$ NMR $\left(500 \mathrm{MHz}, \mathrm{CDCl}_{3}\right) \delta 9.55$ (d, J=15Hz, 2H), 8.88(s, 2H), $8.68(\mathrm{~d}$, $\mathrm{J}=15 \mathrm{~Hz}, 2 \mathrm{H}), 7.64-7.13(\mathrm{~m}, 14 \mathrm{H}), 4.28(\mathrm{t}, \mathrm{J}=10 \mathrm{~Hz}, 4 \mathrm{H}), 3.75(\mathrm{t}, \mathrm{J}=5 \mathrm{~Hz}$, $4 \mathrm{H}), 3.63(\mathrm{~s}, 4 \mathrm{H}) \mathrm{ppm}$; 
${ }^{13}$ CNMR Spectra- 3b (Compound B)

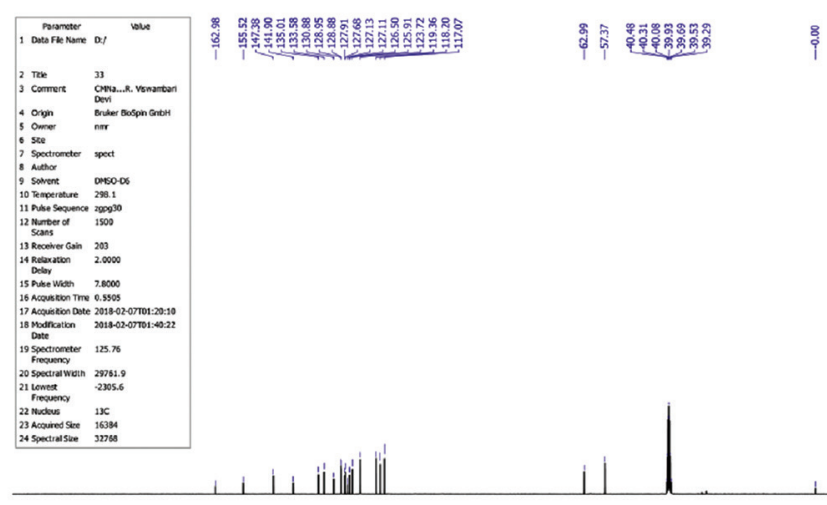

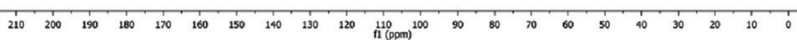

Result analysis

${ }^{13} \mathrm{C}$ NMR $\left(100 \mathrm{MHz}, \mathrm{CDCl}_{3}\right) \delta 162.98,155.52,147.38,141.90,135.01$, $133.58,130.88,128.95,128.88,127.91,127.68,127.13,127.11,126.50$, $125.91,123.72,119.36,118.20,117.07,62.99,57.37$ ppm;

\section{HRMS (ESI) Spectra - 3b (Compound B)}

D:Raw Datal 02-Feb-18 11:59:39 AM

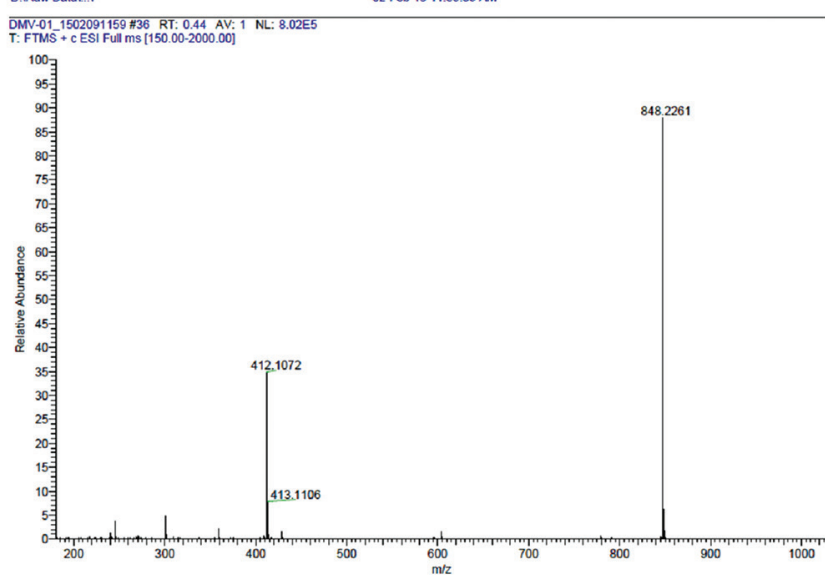

Result analysis

HRMS (ESI): Anal. Calcd. for $\left(\mathrm{C}_{52} \mathrm{H}_{40} \mathrm{~N}_{4} \mathrm{O}_{8}\right)(\mathrm{M}+)$ : 848.2846, Found: 848.2261.

Spectral Results=Compound C Step 2: 5,12-bis(bis(2-hydroxyethyl) amino)-2,9dihexylanthra[2,1,9-def:6,5,10-d'e'f']diisoquinoline1,3,8,10(2H,9H)-tetraone - Compound C.<smiles>CCCCCCN1C(=O)c2ccc3c4c(N(CCO)CCO)cc5c6c(ccc(c7c(N(CCO)CCO)cc(c2c37)C1=O)c64)C(=O)N(CCCCCC)C5=O</smiles>

$\mathbf{R}_{\mathrm{f}}=0.68$ (H: EtOAc/1:1);
IR Spectra - 3c

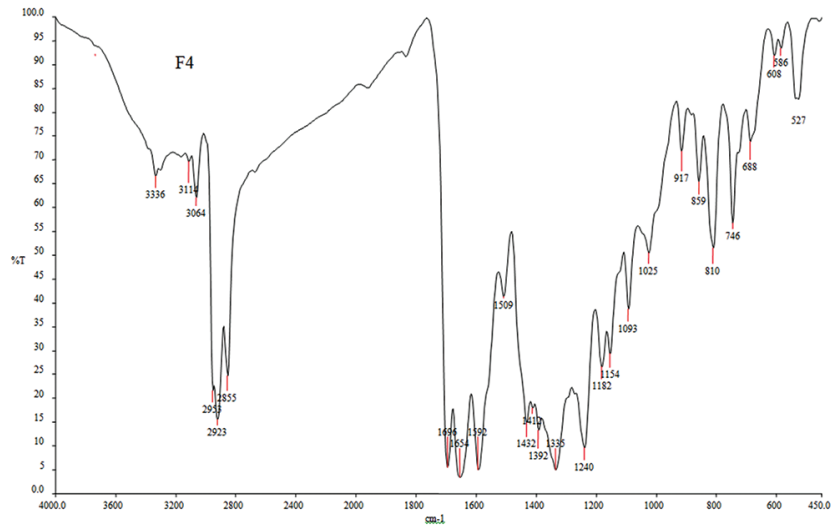

Result analysis

IR ( $\left.\mathrm{KBr}, \mathrm{cm}^{-1}\right)$; Hydroxyl group (3405 $\left.\mathrm{cm}^{-1}\right)$, Amide carbonyl (1733, 1647 $\left.\mathrm{cm}^{-1}\right)$, Aromatic CH $\left(3057 \mathrm{~cm}^{-1}\right)$, Aliphatic $\mathrm{CH}\left(2922 \mathrm{~cm}^{-1}\right), \mathrm{C}=\mathrm{C}\left(1599 \mathrm{~cm}^{-1}\right)$;

${ }^{1}$ HNMR Spectra - 3c (Compound C)

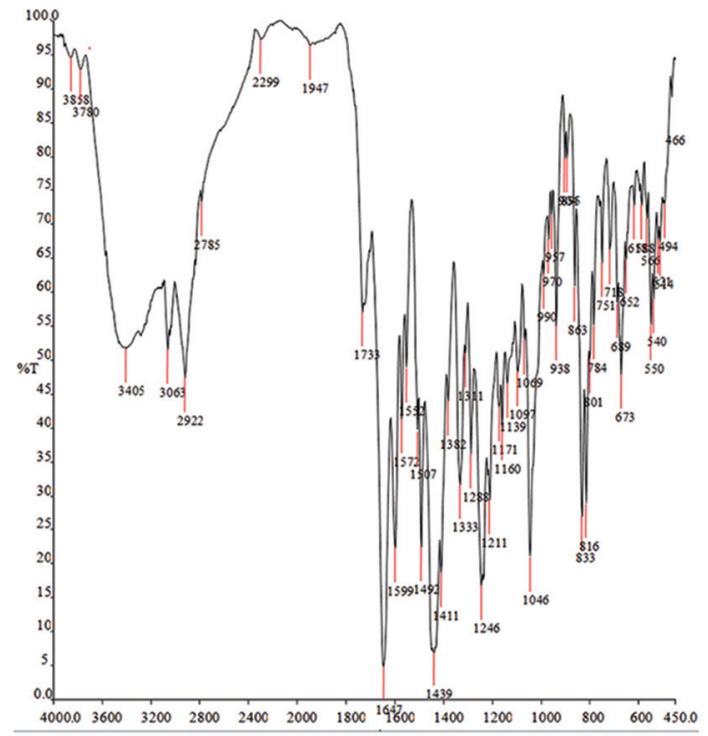

Result analysis

$\left.{ }^{1} \mathrm{H} \mathrm{NMR} \mathrm{(400} \mathrm{MHz,} \mathrm{CDCl}_{3}\right) \delta 9.55(\mathrm{~d}, \mathrm{~J}=10 \mathrm{~Hz}, 2 \mathrm{H}), 8.90(\mathrm{~s}, 2 \mathrm{H}), 8.81(\mathrm{~d}$, $\mathrm{J}=10 \mathrm{~Hz}, 2 \mathrm{H}), 4.52(\mathrm{t}, \mathrm{J}=10 \mathrm{~Hz}, 8 \mathrm{H}), 3.91(\mathrm{t}, \mathrm{J}=5 \mathrm{~Hz}, 8 \mathrm{H}), 3.67(\mathrm{~s}, 4 \mathrm{H}), 3.38$ (t, J=10Hz, 4H), 1.83-1.25 (m, 20H) ppm;

${ }^{13}$ CNMR Spectra - 3c (Compound C)

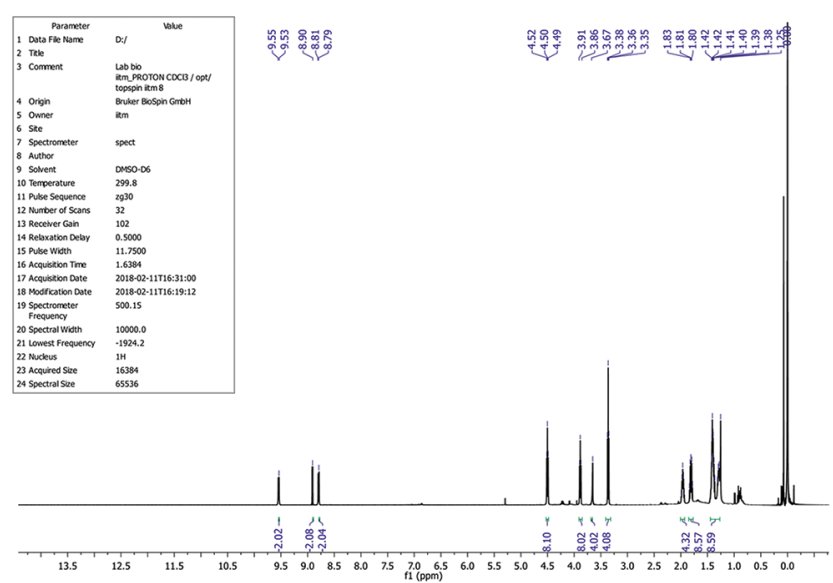




\section{Result analysis}

${ }^{13} \mathrm{C} \mathrm{NMR}\left(100 \mathrm{MHz}, \mathrm{CDCl}_{3}\right) \delta 162.65,144.84,140.82,139.11,137.73,131.14$, $129.25,128.81,127.71,126.15,125.68,125.49,124.22,123.02,119.53$, 109.54, 61.72, 58.47, 41.58, 39.36, 32.74, 29.74, 27.11, 22.90, 14.40 ppm;

\section{HRMS (ESI) Spectra - 3c (Compound C)}

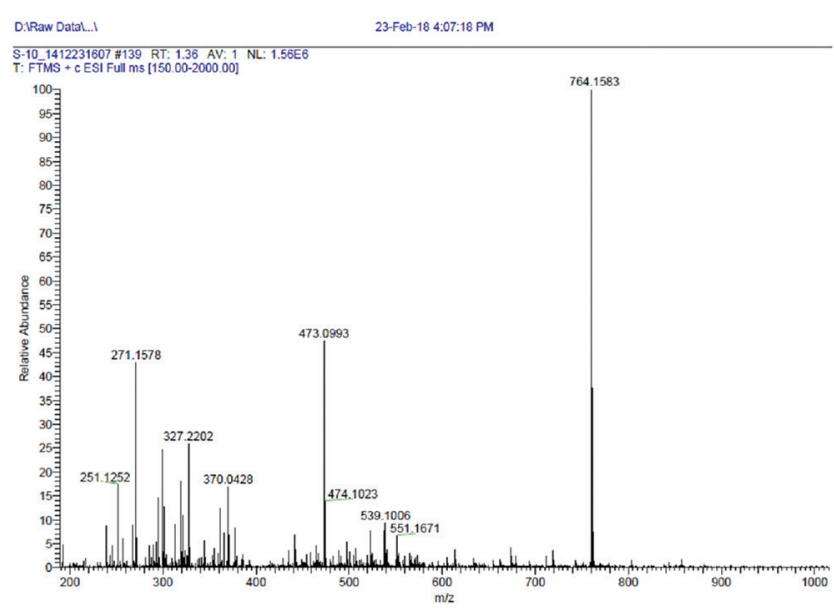

Result analysis

HRMS (ESI): Anal. Calcd. for $\left(\mathrm{C}_{32} \mathrm{H}_{28} \mathrm{~N}_{4} \mathrm{O}_{10}\right)(\mathrm{M}+)$ : 628.1805, Found: 628.7116.

\section{Spectral results}

Compound D Step 2: 1,7-Bis(n-diethanolamino)-N,N-dihydroxylamine3,4,9,10-perylenetetracarboxylic diimides (3d)-Compound D.<smiles></smiles>

$\mathbf{R}_{\mathrm{f}}=0.70$ (H: EtOAc/1:1)

IR Spectra - 3d

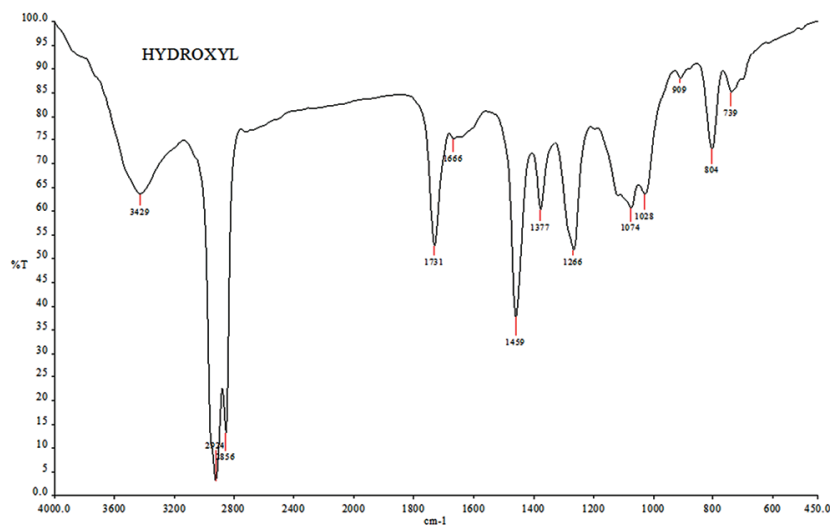

Result analysis

IR (KBr, cm $\left.{ }^{-1}\right)$; Hydroxyl group (3390 $\left.\mathrm{cm}^{-1}\right)$, Amide carbonyl $\left(1727,1667 \mathrm{~cm}^{-1}\right)$, Aromatic $\mathrm{CH}\left(3057,2956 \mathrm{~cm}^{-1}\right)$, Aliphatic $\mathrm{CH}$ $\left(2857 \mathrm{~cm}^{-1}\right), \mathrm{C}=\mathrm{C}\left(1593 \mathrm{~cm}^{-1}\right)$;
${ }^{1}$ HNMR Spectra - 3d (Compound D)

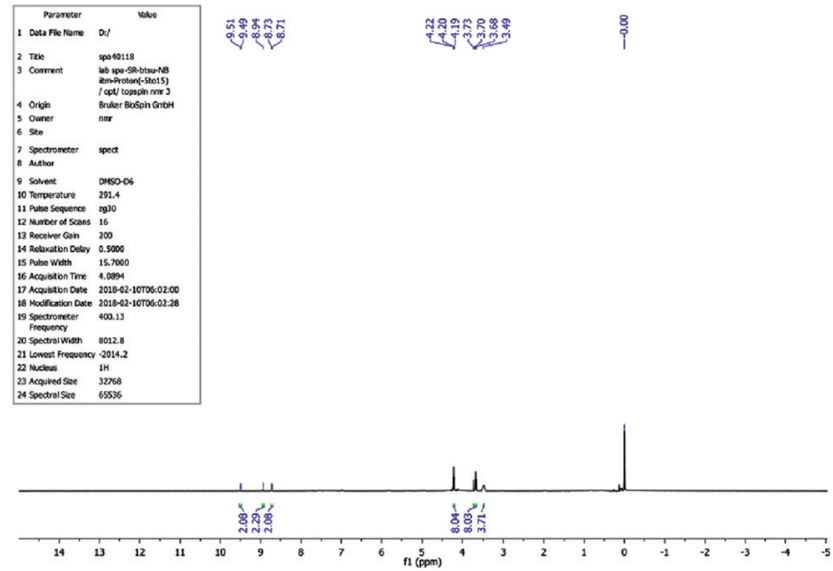

Result analysis

${ }^{1} \mathrm{H}$ NMR $\left(400 \mathrm{MHz}, \mathrm{CDCl}_{3}\right) \delta \mathrm{ppm} ; \delta 9.55(\mathrm{~d}, \mathrm{~J}=10 \mathrm{~Hz}, 2 \mathrm{H}), 8.90(\mathrm{~s}, 2 \mathrm{H})$, $8.81(\mathrm{~d}, \mathrm{~J}=10 \mathrm{~Hz}, 2 \mathrm{H}), 4.52(\mathrm{t}, \mathrm{J}=10 \mathrm{~Hz}, 8 \mathrm{H}), 3.91(\mathrm{t}, \mathrm{J}=5 \mathrm{~Hz}, 8 \mathrm{H}), 3.67$ (s, $4 \mathrm{H}), 3.38(\mathrm{t}, \mathrm{J}=10 \mathrm{~Hz}, 4 \mathrm{H})$

\section{${ }^{13}$ CNMR Spectra - 3d (Compound D)}

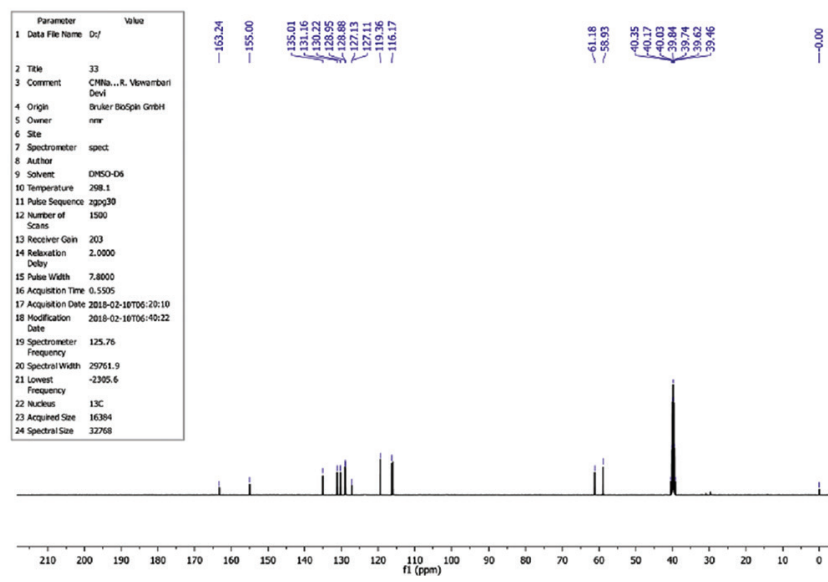

Result analysis

${ }^{13} \mathrm{C}$ NMR $\left(100 \mathrm{MHz}, \mathrm{CDCl}_{3}\right) \delta 9.51(\mathrm{~d}, \mathrm{~J}=10 \mathrm{~Hz}, 2 \mathrm{H}), 8.94(\mathrm{~s}, 2 \mathrm{H}), 8.73(\mathrm{~d}$, $\mathrm{J}=10 \mathrm{~Hz}, 2), 4.22(\mathrm{t}, \mathrm{J}=10 \mathrm{~Hz}, 8 \mathrm{H}), 3.73(\mathrm{t}, \mathrm{J}=10 \mathrm{~Hz}, 8 \mathrm{H}), 3.49$ (s, 4H) ppm;

\section{HRMS (ESI) Spectra - 3d (Compound D)}

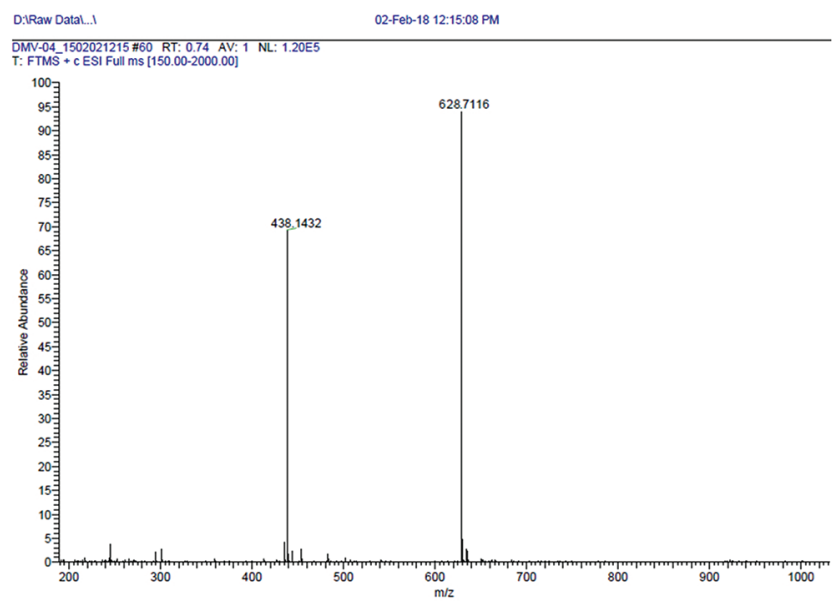

Result analysis

HRMS (ESI): Anal. Calcd. for $\left(\mathrm{C}_{32} \mathrm{H}_{28} \mathrm{~N}_{4} \mathrm{O}_{10}\right)(\mathrm{M}+)$ : 628.1805, Found: 628.7116 


\section{In vitro studies}

Anti oxidant assay: Free radical scavenging ability by the use of a stable 1,1-diphenyl-2-picryl hydrazyl (DPPH) radical (DPPH)

The effect of the perylene di imides on DPPH radical was estimated according to the procedure described by Von Gadow etal. $2 \mathrm{~mL}$ of $6 \times 10^{-5}$ M methanolic solution of DPPH was added to $50 \mu \mathrm{l}$ of a methanolic solution $(10 \mathrm{mg} / \mathrm{mL})$ of the sample. Absorbance measurements commenced immediately [16,17]. The decrease of absorbance at $515 \mathrm{~nm}$ was continuously recorded in a spectrophotometer for $16 \mathrm{~min}$ at room temperature all determinations were performed in triplicate.

\section{Nitric oxide scavenging activity}

Nitric oxide generated from sodium nitroprusside in aqueous solution at physiological $\mathrm{pH}$ was measured by Griess reaction $[18,19]$. The reaction mixture $(3 \mathrm{~mL})$ containing sodium nitroprusside $(10 \mathrm{~mm})$ in phosphate buffer saline and the test extract $(10,25,50$ and 100 $\mu \mathrm{g} \mathrm{mL}$ ) was incubated at $25^{\circ} \mathrm{C}$ for $150 \mathrm{~min}$, after incubation $1.5 \mathrm{~mL}$ of the reaction mixture was removed and $1.5 \mathrm{~mL}$ of the Griess reagent (1\% sulphanilamide, $2 \%$ orthophosphoric acid and $0.1 \%$ napthylethyline diamine hydrochloride) was added. The absorbance of the chromophore formed was read at $546 \mathrm{~nm}$.

In vitro cell cytotoxicity estimation by 3-(4,5-dimethylthiazol2-yl)-2,5-diphenyltetrazolium bromide (MTT) assay

Cell line

The Human colon cancer cell line (HCT 116) was obtained from National Centre for Cell Science, Pune and grown in Eagles Minimum Essential Medium containing 10\% fetal bovine serum [20,21]. The cells suspended in the medium by a gentle passage with the pipette and the cells homogenized. Seeding of cells One $\mathrm{mL}$ of the homogenized cell suspension was added to each well of a 24 well culture plate along with different concentration of butylamine, napthalamine, hexylamine and hydroxylamine perylene derivatives (i.e., $0-250 \mu \mathrm{g} / \mathrm{mL}$ ) and incubated at $37^{\circ} \mathrm{C}$ in a humidified $\mathrm{CO}_{2}$ incubator with $5 \% \mathrm{CO}_{2}$. After $48 \mathrm{~h}$ incubation, the cells were observed under an inverted tissue culture microscope. With $80 \%$ confluence of cells, cytotoxicity assay was carried out.

\section{MTT assay}

\section{Cytotoxicity assay}

The assay was carried out using MTT. MTT is cleaved by mitochondrial Succinate dehydrogenase and reductase of viable cells, yielding a measurable purple product formazan [22,23]. This formazan production is directly proportional to the viable cell number and inversely proportional to the degree of cytotoxicity. After $48 \mathrm{~h}$ incubation, the wells were added with MTT and left for $3 \mathrm{~h}$ at room temperature. All wells have removed the content using the pipette and $100 \mu \mathrm{l}$ safety data sheets in dimethyl sulfoxide was added to dissolve the formazan crystals, absorbances were read in Multiskan "' FC Microplate Photometer at $570 \mathrm{~nm}$ (Mosman 1983).

- The percentage cell viability was then calculated with respect to control as follows:

$\%$ Cell viability $=[\mathrm{A}] \mathrm{Test} /[\mathrm{A}]$ control $\times 100$

- The $\%$ cell inhibition was determined using the following formula. $\%$ Cell Inhibition $=100-$ Abs (sample) $/$ Abs (control) $\times 100$.

\section{RESULTS}

Molecular modeling study helps to open future de nova modeling of the new compound to treat cancer. Based on the in silico studies, we have chosen compound 11 as the scaffold moiety and to synthesis the perylene derivatives from the Scaffold. From the literature survey scheme for the synthesis have been drawn and bromination of perylene di imides has been done condensed with amines. Antioxidant assay and Anticancer activity showed Compound A has significant activity when compared with the standard Drug 5-Flurouracil.

\section{DISCUSSIONS}

Anti oxidant Assay showed a maximum activity of $44.2 \%$ and $28.93 \%$ respectively at $1000 \mu \mathrm{g} / \mathrm{mL}$, whereas an ascorbic acid at the same concentration exhibited $97.40 \%$ inhibition respectively. Four different amines exhibited considerable DPPH free radical scavenging activity as indicated by their $\mathrm{IC}_{50}$ values and this has been shown in (Table 2). $\mathrm{IC}_{50}$ Indicate the potency of scavenging activity. Standard ascorbic acid found to have an $\mathrm{IC}_{50}$ of $0.052 \mathrm{mg} / \mathrm{mL}$. In comparison to standard ascorbic acid, butyl amine naphthylamine, hexyl and hydroxyl amine derivatives of perylene compounds showed of 5.311, 1.246, 2.611 and 1.753 respectively. Butyl and Hydroxyl derivatives are seen to have the least free radical scavenging activity. Nitric oxide scavenging assay has done and perylene compounds has potent nitric oxide scavenging activity of $42.31 \%, 37.18 \%$ \& $26.92 \%$ respectively at $1000 \mu \mathrm{g} / \mathrm{mL}$, where as Quercetin at the same concentration exhibited $85.96 \%$ inhibition respectively. These amines exhibited considerable Nitric Oxide scavenging activity as indicated by $\mathrm{IC}_{50}$ value $1.462,1.429$ and $1.765 \mathrm{mg} / \mathrm{mL}$ for compound A, B and C, whereas Hydroxyl amine perylene derivative has showed the least nitric oxide scavenging activity of $\mathrm{IC}_{50}$ value $4.147 \mathrm{mg} / \mathrm{mL}$ (Table 3 ). The scavenging of NO by the extracts was increased in dose dependent manner. A significant decrease in the NO radical due to the scavenging ability of the compounds and these are compared with Quercetin and the $\mathrm{IC}_{50}$ was found to be $0.518 \mathrm{mg} / \mathrm{mL}$.

\section{In-vitro cell cytotoxicity analysis by MTT assay}

The study was undertaken to determine the cell cytotoxicity of the synthesized compounds by MTT assay. HCT-116 cell line is a colon cancer cell line was taken and also the study helps to screen the best compound which is successfully able to kill the cancer cells $[24,25]$. Therefore, a cell viability graph was also plotted to understand the result. The study was designed with a single cell line (HCT-116) and different ligands in different concentrations. Therefore eight concentrations $(0.1 \mu \mathrm{M}, 1 \mu \mathrm{M}, 10 \mu \mathrm{M}, 50 \mu \mathrm{M}$ and $100 \mu \mathrm{M})$ for $24 \mathrm{~h}$ and $48 \mathrm{~h}$, were fixed to understand the inhibition of the cell viability in a dose-response manner. 5-Fluorouracil was taken as a standard drug for this study, by injection into a vein it is used for colon cancer. The three prototypes of perylene amine derivatives are treated with Normal Vero cells to study the cell viability \%. A viability assay is an assay to determine the ability of organs, cells or tissues to maintain or recover viability. The results of the three prototypes along with the standard are tabulated in Table 4. Among the three prototypes, only Compound A and Compound $\mathrm{B}$ showed immaculate activity in dose-response manner. Compound A successfully able to kill cancer cell and also showed $32.37 \mu \mathrm{M} \mathrm{IC}_{50}$ value. Compound A also showed potent cell population inhibition in $50 \mu \mathrm{M}$ and $100 \mu \mathrm{M}$. The percentage of cell inhibition at the highest concentration was found to be $94.53 \%$. The standard compound 5-Fluorouracil showed $26.923 \mu \mathrm{M} \mathrm{IC}_{50}$, which is proximately closer to the synthesized compound (Compound A). The concentration of drug-treated with HCY116 colon cancer cells are plotted for three compounds (A, B and C) are compared with a standard drug. Compound B also successfully showed potent activity towards the cell line (HCT-116, colon cancer cell line). The $\mathrm{IC}_{50}$ value of the compound was found to be $35.67 \mu \mathrm{M}$. The percentage of cell inhibition at the highest concentration was found to be $91.79 \%$. The standard compound 5-Fluorouracil showed $26.93 \mu \mathrm{M} \mathrm{IC}_{50}$, which is proximately nearer to the synthesized compound (Compound B). Regression analysis was also done. $\mathrm{R}^{2}$ value of Compound $\mathrm{A}$, Compound $\mathrm{B}$ and 5-Fluorouracil (Standard) were found to be 0.797, 0.790, and 0.809 respectively. Compound C doesn't have much potent towards the HCT-116 colon cancer cell line when compared with Compound A, B and with the standard Drug 5-Fluorouracil. The consolidated flowchart of inhibition of drug with respect to the concentration was depicted in Table 5 and Fig. 1. Colon cancer Cell lines treated with different concentrations of the compounds A, B, C and Standard drug (5-Fluorouracil) are represented in Fig. 2.

\section{CONCLUSION}

The study was undertaken to find out, a single novel molecule which can be used for multiple targets for different types of cancers. The 


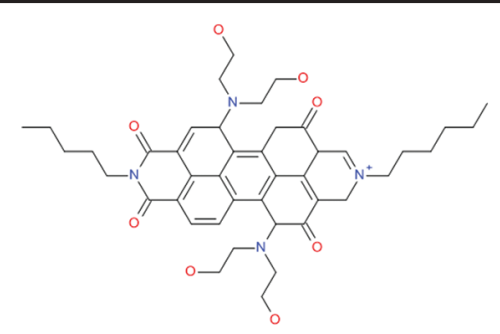

Compound A

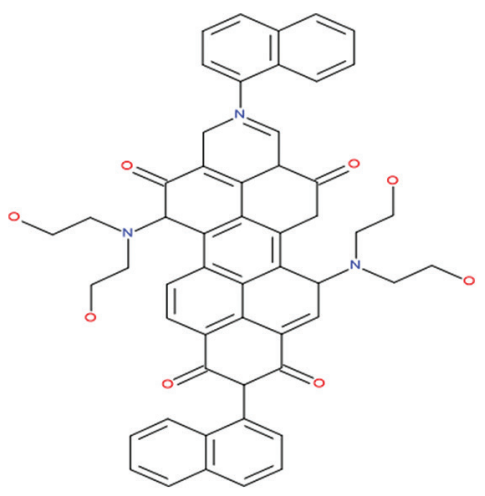

Compound C

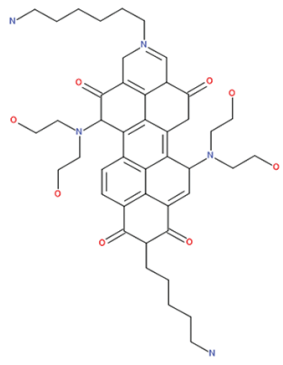

Compound B

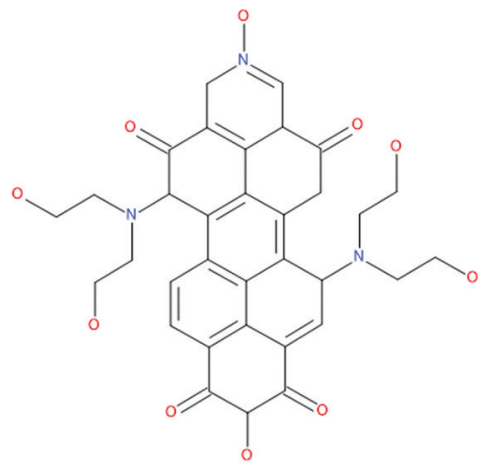

Compound D

Table 2: DPPH free radical scavenging assay

\begin{tabular}{lllllll}
\hline Compound & Control & $\mathbf{2 0 0}$ & $\mathbf{4 0 0}$ & $\mathbf{6 0 0}$ & $\mathbf{8 0 0}$ & $\mathbf{1 0 0 0}$ \\
\hline A & $0.629(0)$ & $0.56(10.97)$ & $0.554(11.92)$ & $0.546(13.2)$ & $0.533(15.26)$ & $0.522(17.01)$ \\
OD (\%) & $0.629(0)$ & $0.56(29.09)$ & $0.554(38.79)$ & $0.546(39.9)$ & $0.533(42.77)$ & $0.522(44.2)$ \\
OD (\%) & $0.629(0)$ & $0.56(0.16)$ & $0.554(8.43)$ & $0.546(15.58)$ & $0.533(21.14)$ & $0.522(24.96)$ \\
C & $0.629(0)$ & $0.56(16.22)$ & $0.554(16.69)$ & $0.546(19.55)$ & $0.533(20.67)$ & $0.522(28.93)$ \\
D (\%) & $0.169(0)$ & $0.561(76.85)$ & $0.582(79.73)$ & $0.626(85.75)$ & $0.658(90.14)$ & $0.711(97.40)$ \\
OD (\%) & & & & &
\end{tabular}

DPPH: 1,1-Diphenyl-2-picryl hydrazyl

Table 3: Nitric oxide scavenging assay

\begin{tabular}{lllllll}
\hline Compound & Control & $\mathbf{2 0 0}$ & $\mathbf{4 0 0}$ & $\mathbf{6 0 0}$ & $\mathbf{8 0 0}$ & $\mathbf{1 0 0 0}$ \\
\hline A & $0.390(0)$ & $0.282(27.69)$ & $0.26(33.33)$ & $0.251(35.64)$ & $0.242(37.95)$ & $0.225(42.31)$ \\
OD (\%) & $0.390(0.00)$ & $0.34(12.82)$ & $0.292(25.13)$ & $0.28(28.21)$ & $0.266(31.79)$ & $0.245(37.18)$ \\
B & $0 D(\%)$ & $0.385(1.28)$ & $0.355(8.97)$ & $0.334(14.36)$ & $0.315(19.23)$ & $0.285(26.92)$ \\
C & $0.390(0)$ & $0.389(0.26)$ & $0.382(2.05)$ & $0.371(4.87)$ & $0.361(7.44)$ & $0.35(10.26)$ \\
OD (\%) & $0.390(0)$ & $0.464(20.55)$ & $0.324(44.52)$ & $0.236(59.59)$ & $0.157(73.12)$ & $0.082(85.96)$ \\
D OD (\%) & $0.584(0)$ & & & &
\end{tabular}

perylene di-imides were used as a G-Quadruplex stabilizer, which can be stabilized and inactivate telomerase protection towards telomere, which promotes apoptosis. QSAR studies have been carried out using standard perylene compounds targeting telomerase by QSAR PLUS Module- Vlife Software. Around 491 compounds have been drawn using accelrys draw and studies. From the results, 59 compounds are selected for docking using G4LDB, patch Dock Server, and AutoDock by using selective G-Quadruplex targets (1NZM, 3CE5, 1L1H and 4B18).
9 compounds are selected from the three docking results based upon the binding free energy, pki, complementary shape analysis. These 9 compounds are compared with the standard drug PIPER and the interactions are visualized by Discovery studio Visualizer 4.1. Among the 9 compounds, 2 compounds (Compound 11 and 20) possess best interactions with the receptor and may have potent inhibitory effect against the telomerase enzyme for anti-cancer activity. From the 2 compounds Compound, 11 was chosen as a scaffold for synthesis. The 
synthesis has been designed as bromination of Perylene Di imides at position $1^{\text {st }}$ and $7^{\text {th }}$ position and then condensed with amines, finally alkylation with Diethanolamine to remove the bromine as $\mathrm{HBr}$. We have synthesized four PDI prototypes and characterized by FT-IR, ${ }^{1} \mathrm{HNMR}$, ESI-Mass and also purified by column chromatography with

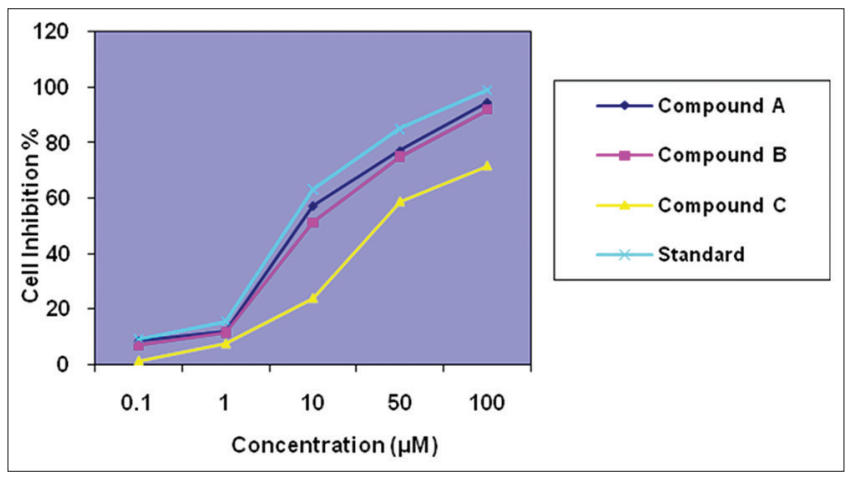

Fig. 1: Consolidated table of concentration of drugs versus cell inhibition \% - HCT-116 colon cancer cells a combination of solvents. We have taken a colon cancer cell line i.e. HCT-116 to screen our three ligands (Compound A, B and C) by MTT assay for understanding the cell cytotoxicity towards the cancer cells. Ligands were chosen based on the elaborate molecular modeling study to prove our hypothesis. The molecular modeling data's are exactly correlated with the in vitro studies. We have used 5-Fluorouracil and PIPER as a standard for in vitro study and molecular modeling study respectively. In vitro study revealed that Compound A and Compound $\mathrm{B}$ were remarkably able to kill the cancer cells as per the hypothesis being made earlier. Compound A and Compound B showed significant activity with respect to 5-Fluorouracil. Molecular modeling study helps to open future de novo modeling of a new compound to treat cancer. Other compounds were failed to show promising cytotoxicity towards cell line. The compounds will be exposed to other human cancer cell lines to understand the molecular mechanism of the ligands for the future prototypes.

\section{ACKNOWLEDGMENTS}

The authors are thankful to Vels Institute of Science, Technology and Advanced Studies (VISTAS) and its management for providing research facilities and encouragement. The author is obliged to

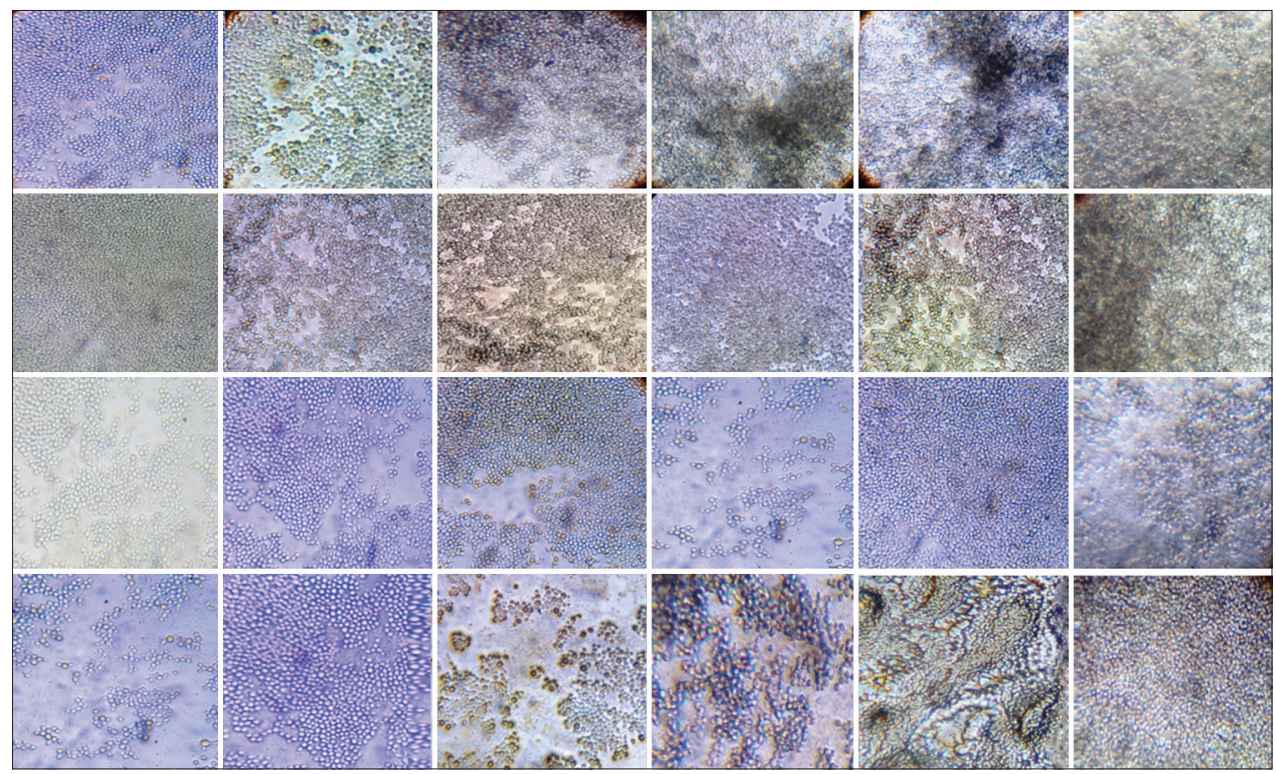

Figs. 2: Compound A, B, C and standard compound (5-fluorouracil) treated with HCT-116 cell line in different concentrations (i) $0.1 \mu \mathrm{m}$ (ii) $1 \mu \mathrm{m}$ (iii) $10 \mu \mathrm{m}$ (iv) $50 \mu \mathrm{m}$ (v) $100 \mu \mathrm{m}$ (vi) Control

Table 4: Consolidated table of concentration of drugs versus cell viability \% - normal Vero cells

\begin{tabular}{llllll}
\hline S. No & Concentration $(\boldsymbol{\mu M})$ & Compound A & Compound B & Compound C & Standard Drug \\
\hline 1 & 0.1 & 95.13 & 98.63 & 96.86 & 98.11 \\
2 & 1 & 90.09 & 94.87 & 89.90 & 94.82 \\
3 & 10 & 88.61 & 91.56 & 88.22 & 87.34 \\
4 & 50 & 83.46 & 84.95 & 82.15 & 82.30 \\
5 & 100 & 80.50 & 82.21 & 78.68 & 78.21 \\
\hline
\end{tabular}

Table 5: Consolidated table of concentration of drugs versus cell inhibition \% - HCT-116 colon cancer cells

\begin{tabular}{llllll}
\hline S. No & Concentration $(\boldsymbol{\mu M})$ & Compound A & Compound B & Compound C & Standard Drug \\
\hline 1 & 0.1 & 8.50 & 6.95 & 1.30 & 9.05 \\
2 & 1 & 11.94 & 11.58 & 7.53 & 15.43 \\
3 & 10 & 57.29 & 51.16 & 23.90 & 63.17 \\
4 & 50 & 77.13 & 74.95 & 58.78 & 84.98 \\
5 & 100 & 94.53 & 91.79 & 71.69 & 98.97 \\
6. & IC50 & $32.37 \mu \mathrm{M}$ & $35.67 \mu \mathrm{M}$ & $57.46 \mu \mathrm{M}$ & $26.93 \mu \mathrm{M}$ \\
\hline
\end{tabular}


DBT - Government of India (BT/Bio-care/03/10047/2013-14) for providing financial assistance to carry out the research work.

\section{AUTHORS CONTRIBUTION}

The authors are equally contributed to the research work and preparing the manuscript.

\section{CONFLICTS OF INTERESTS}

The authors declare no conflict of interest.

\section{REFERENCES}

1. Schwab M. Encyclopedia of Cancer. $2^{\text {nd }}$ ed. New York: Springer; 2008. p. 310-2

2. Antonio MD, Rodriguez R, Balasubramanian S. Experimental approaches to identify cellular G-Quadruplex structures and functions. Methods 2012;57:84-92.

3. Sen D, Gilbert W. Formation of parallel four-stranded complexes by guanine-rich motifs in DNA and its implications for meiosis. Nature 1988;334:364-6

4. Davis JT. G-quartets 40 years later: From 5'-GMP to molecular biology and supramolecular chemistry.Chem. Int Ed Engl 2004;43:668-98.

5. Brya TM, Baumann P. G-Quadruplexes: From guanine gels to chemotherapeutics. Mol Biotechnol 2011;49:198-208.

6. Patel DJ, Phan AT, Kuryavyi V. Human telomere, oncogenic promoter and 5'-UTRG-quadruplexes: Diverse higher order DNA and RNA targets for cancer therapeutics. Nucleic Acids Res 2007;35:7429-55.

7. Grand CL, Han H, Muñoz RM, Weitman S, Von Hoff DD, Hurley LH, et al. The cationic porphyrin tmpyp4 down-regulates c-MYC and human telomerase reverse transcriptase expression and inhibits tumor growth in vivo. Mol Cancer 2002;1:565-73.

8. Lu YJ, Ou TM, Tan JH, Hou JQ, Shao WY, Peng D, et al. 5-N-methylated quindoline derivatives as telomeric g-quadruplex stabilizing ligands: Effects of 5-N positive charge on quadruplex binding affinity and cell proliferation. J Med Chem 2008;51:6381-92.

9. Bejugam M, Sewitz S, Shirude PS, Rodriguez R, Shahid R, Balasubramanian S. Trisubstituted isoalloxazines as a new class of g-quadruplex binding ligands: Small molecule regulation of c-kit oncogene expression. J Am Chem Soc 2007;129:12926-7.

10. Duan W, Rangan A, Vankayalapati H, Kim MY, Zeng Q, Sun D, et al. Design and synthesis of fluoroquinophenoxazines that interact with human telomeric g-quadruplexes and their biological effects. Mol Cancer Ther 2001;1:103-20.

11. Hemalatha CN, Aanandhi MV. G-Quadruplex ligands as stabilizer targeting telomerase as anti-cancer agents. Asian J Pharm Clin Res 2017; $10: 50-3$
12. Hemalatha CN, Aanandhi MV. 3D QSAR and docking study of perylene- di imides analogues as potent apoptosis inducer and efficacious anticancer agent. Indian Drugs 2017;54:15-27.

13. Hemalatha CN, Aanandhi MV. Application of 3D QSAR and docking studies in optimization of perylene di imides as anti cancer agent. Indian J Pharm Educ Res 2018;52:46-54.

14. Sissi C, Lucatello L, Krapcho AP, Maloney DJ, Boxer MB, Camarasa MV, et al. Tri-, tetra- and heptacyclic perylene analogues as new potential antineoplastic agents based on DNA telomerase inhibition. Bioorg Med Chem 2007;15:555-62.

15. Taner K, Belgin SI, Yasemin GI, Funda Y. Evaluation of perylenediimide derivatives for potential therapeutic benefits on cancer chemotherapy. Chem Biol Drug Des 2012;80:675-81.

16. Von Gadow A, Joubert E, Hansmann CF. Comparison of antioxidant activity of aspalathin with that of other plant phenols of Rooibosed tea (Aspalathon linearis), $\alpha$-tocopherol, BHT and BHA. J Agric Food Chem 1997;45:632-8

17. Yen GC, Duh PD. Scavenging effect of methanolic extracts of peanut hulls on free-radical and active oxygen species. J Agric Food Chem 1994:42:629-32.

18. Marcocci I, Marguire JJ, Droy-Lefaiz MT, Packer L. The nitric oxide scavenging properties Ginkgo biloba extract. Biochem Biophys Res Commun 1994;201:748-55.

19. Shahriar M, Hossain I, Sharmin FA, Akhter S, Haque A, Bhuiyan MA. In vitro antioxidant and free radical scavenging activity of Withania somnifera Root. IOSR J Pharm 2013;3:38-47.

20. Abondanza TS, Oliveria CR, Barbosa CM. Bcl-2 expression and apoptosis induction in human HL-60 leukaemic cells treated with a novel organotellurium compound RT-04. Food Chem Toxicol 2008;46:2540-45.

21. Mosmann T. Rapid colorimetric assay for cellular growth and survival: Application to proliferation and cytotoxicity assays. J Immunol Methods 1983;65:55-63.

22. Lakshmi S, Dhanaya GS, Joy B, Padmaja G, Remani P. Inhibitory effect of an extract of Curcuma zedoaria on human cervical carcinoma cells. Med Chem Res 2008;17:335-44

23. Rossetti L, Franceschin M, Schirripa S, Bianco A, Ortaggi G, Savino M. Selective Interactions of Perylene derivatives having different side chains with inter- and intramolecular G-Quadruplex DNA Structures. A correlation with telomerase inhibition. Luigi Rossetti, Marco Franceschin. Bioorg Med Chem Lett 2005; 15:413-20.

24. Sarvesh $\mathrm{H}$, Vimal K. In vitro cytotoxicity effect On MCF-7 cell line of co-encapsulated artesunate and curcumin liposome. Int J Pharm Pharm Sci 2017;9:123-8.

25. Bashari MH, Hidayat S, Ruswandi YA, Putri T, Qomarilla N, Dwiwina RG. The N-Hexane fraction of Myrmecodia pendans inhibits cell survival and proliferation in colon cancer cell line. Int J Pharm Pharm Sci 2018;10:108-12. 